\title{
The Debt Status of Commercial Company under Gharimin Perspective
}

\author{
Eja Armaz Hardi a, Sirajul Arifin b, Burhan Djamaluddin ${ }^{c}$ \\ ${ }^{a}$ Faculty of Islamic Economics and Business, UIN Sultan Thaha Saifuddin Jambi, Indonesia \\ ${ }^{b}$ Faculty of Islamic Economics and Business, UIN Sunan Ampel Surabaya, Indonesia \\ c Postgraduate Program, UIN Sunan Ampel Surabaya, Indonesia \\ Corresponding email: eja.armaz.hardi@uinjambi.ac.id \\ doi http://dx.doi.org/10.22515/shirkah.v6i1.388
}

\begin{tabular}{|c|c|}
\hline ARTICLE INFO & ABSTRACT \\
\hline $\begin{array}{l}\text { Keywords: } \\
\text { Commercial Company; Debt } \\
\text { Status; Gharim; Gharimin; } \\
\text { Zakat } \\
\text { Article history: } \\
\text { Received: } 23 \text { February } 2021 \\
\text { Revised: } 23 \text { March } 2021 \\
\text { Accepted: } 25 \text { March } 2021 \\
\text { Available online: } 06 \text { April } 2021 \\
\text { To cite in APA style: } \\
\text { Hardi, E. A., Arifin, S., \& } \\
\text { Djamaluddin, B. (2021). The } \\
\text { Debt Status of Commercial } \\
\text { Company under Gharimin } \\
\text { Perspective. Shirkah: Journal of } \\
\text { Economics and Business, 6(1), 66- } \\
\text { 82. }\end{array}$ & $\begin{array}{l}\text { Currently, commercial entity companies are not regarded yet } \\
\text { as one of the groups that receive the zakat. This paper examines } \\
\text { the debt status and its micro and macro-economic implications } \\
\text { of corporations that experienced the debt shackled in the zakat } \\
\text { system through analogy on personal gharim (person in the } \\
\text { burden debt). The analysis presented here has been designed } \\
\text { on a library research, an analogy method, as well as seen from } \\
\text { a debt trap theory. This paper particularly argues that in the } \\
\text { twist condition of enterprises to repay their debt, a commercial } \\
\text { company may be entitled as the recipient of zakat on behalf of } \\
\text { gharim (the fifth group who receives the zakat). It further } \\
\text { argues that the loan of the commercial company has a larger } \\
\text { impact than individual gharim. Synchronizing the entity } \\
\text { companies as "syakhsun i'tibariyun" (the legal person) to the } \\
\text { personal obligation to pay zakat is matched to be the reasons } \\
\text { for their gharim's status. The results of this paper contribute to } \\
\text { expanding the recipient of zakat on behalf of gharim and } \\
\text { enhance the insight of zakat distribution in Islamic } \\
\text { philanthropy institutions. }\end{array}$ \\
\hline
\end{tabular}

This work is licensed under a Creative Commons Attribution-NonCommercial 4.0 International License.

\section{Introduction}

Nowadays, not only a person deals with the debt but also the legal entity company. For personal purposes, the debt becomes a solution to fulfil basic (Abdul Aziz et al. 2017) and to meet short-term needs in the state of urgency (Bensaid et al. 2013), and it uses as a source of funding for companies to overcome liquidity's matter for increasing or expanding productivity. The debt may trap the debtors because of the financial ability declining to pay off their loans. From the Islamic teaching perspective, unpaid debt becomes debtor anxiety because it affects personal psychology, social relationship, 
economics, and is converted to afterlife consequences.

Islam has provided a system to unravel those difficulties by assisting the debtor who is not able to pay off his debt as one of the groups who receive zakat on behalf of gharim (al-Qaradawi, 1973a). The ultimate goal of this support is liberating the debtors from the debt bondage (Spradlley, 1979). Therefore, some zakat institutions distribute the zakat to them consistently, like individual gharim, and they have not intended the legal entities as the recipient of zakat, especially commercial companies (Hamdi 'Abdul Karim, 2016). Interestingly, on the other hand, the entity companies have been determined as muzakki to pay zakat in case of their wealth reaches the nisab (Hafidhuddin, 2002; Zaenal, 2019), but they do not become one of the parties that are supported by zakat when they have experience in burden debt. From this discourse, the authors argue that it needs a holistic investigation to find a comprehensive view.

Several studies on gharim in the zakat system have written by scholars of Islamic economics. Abdullah and Haqqi (2017) researched the expanding of the gharim category in the Brunei Darussalam zakat board. They found that the gharim has been expanded into the person in the burden-debt on several daruri and hajiah necessities and become a zakat recipient, such as car credit, government housing, bank loan, and etc. Yusof and Tahir (2015) found that the Malaysian zakat board does not have a comprehensive terminology of gharim to accommodate all aspects of the loan. Further, the National Amil Zakat Board (BAZNAS) in Indonesia excluded the rich people who shackled by debt with a business purpose to become gharim (BAZNAS, 2019). In contrast to previous studies, Abdul Rahim (2015) concluded that the Sudanese zakat institution permitted the indebtedness person that spent his debt on commercial business as gharim, while the bankrupt company has disqualified from gharim who receive the zakat. On the other hand, Hamdi 'Abdul Karim (2016) argued that the only company that enables to be entitled as gharim is the legal entity which has social purposes and humanitarian activities for the poor and needy, such as non-commercial organization, an education, or an orphan foundation.

Furthermore, research on gharim has recently talked about how the zakat distribution and utilization for gharim. Hamzah et al. (2021) found that gharim used zakat to fulfill the basic needs, buy food and drink, and help the gharim's family. The consumptive allocation of gharim was resulted from the non-united terms of gharim implemented in the philanthropy institution (Ibrahim, 2020). Thus, an adjustment of the gharim category is required to counterbalance the expanding of the debt model and social interaction (Hakim, 2018), such as owning the first house and vehicle (Ibrahim \& Sahrim, 2019). On the other hand, the scholars concluded that the Islamic philanthropy institution tried to enlarge the parties who obligated to pay zakat or expanding the object of zakat (Fauzia, 2017; Hardi, 2020; Latief, 2016). Moreover, a small number of 
scholars talk about the gharim category for the bad-debt of the commercial company.

Having explored the above-mentioned results of previous studies, this paper focuses on examining the debt status and its disadvantages in the commercial companies which lose their ability to repay the debt under the gharim framework. The unpaid debt of the commercial company has accumulated the drawbacks for micro and macroeconomic of the nation. Meanwhile, the company has been obligated to pay zakat. The arisen questions from the given discourses above are: (1) how is the implication of bad-debt in micro and macroeconomic?; (2) how is the status of the legal entity company (syakhsun i'tibariyun) in the zakat system?; and (3) is the shackled of the commercial company fit as the recipient of zakat under the gharim framework? This paper contributes to enrich the insights about zakat recipients and minimalizing the debt implication to the macroeconomic. Furthermore, the novelty of this paper showed the discourse-expanding of gharim who receive the zakat. The practical implication of this paper is designated that the burden-debt company experience should be a gharim.

\section{Method}

\section{Research Design}

To arrive at the objectives, this paper was formulated in a library research. The present paper also elaborated the ijtihadi method to delineate to object being studied. Thus, in this paper, the main area of the study is the reasoning of the analogy of zakat obligation upon the legal company. There are three aspects explored in this paper. First, the debt implications for personal life and its family, social interaction, and macroeconomic implications. Second, the zakat obligation upon the legal company. Third, the drawbacks caused by bad-debt of the legal entity and its status in gharim law. Furthermore, it examines, analyzes, and interprets the background of the legal decision of the zakat obligation for legal entity company. In this paper, the theory of gharim and the status of legal entity company on zakat system has been explored to seek a comprehensive point of view on the research objectives. Meanwhile, this paper also expressed the burden-debt implications for personal matter through Al-Quran and hadith of Prophet Muhammad (peace be upon him) and macroeconomic implications through debt trap theory (Jiyad, 2001).

\section{Data Sources and Data Collection}

The data involved in this paper were primary and secondary. The primary data of this paper have highlighted the consensus of the zakat obligation of the legal entity. It has referred to the First International Congress on zakat held by the Organization of Islamic Cooperation on Zakat in 1984 in Kuwait. The secondary data have been collected from several ways; previous works of the scholars, best practices of zakat management in 
various Islamic countries, and the act law as guidance of zakat management. The two types of data have collected online. This paper utilized the research engine (Google Scholar, Science-Direct, Springer, and another research indexing), research application (Publish or Perish), and seeking the data from relevant institutions (website of Central Bank of Indonesia/BI and Financial Service Authority/OJK).

\section{Data Analysis}

The data analysis in this paper was conducted through collecting several relevant works of previous scholars, practices of zakat management from Zakat Board (i.e. Indonesia, Sudan, Malaysia, and Brunei Darussalam), law act correlated to debt and gharim, and research papers on debt-trap. Before bridging into the analogy between personal gharim and the commercial company debt, the first step attempted is analyzing and seeking the implication of un-paid debt for personal life macroeconomic, positioning the legal company in the zakat system. The analogical object of the zakat obligation on the legal entity company by scholars also addressed in this paper. According to Amin al-Shinkity (2001), there are four conditions of the analogy method. The first is the primary law (hukm al-asl). The primary law in this paper was represented by personal gharim as zakat recipient. The second is sub-case $\left(f a r^{\prime} u\right)$. This requirement is the legal entity company that experienced the burden-debt and has been used as an analogic sub-case. The third is reason (illah). The reason means the background used to establish the legal decision. The analogical reasons in both cases in this paper are the background of designating personal burden-debt as gharim and its implications. The last is law (hukm) that was the legal impact of analogy (Mukhtar al-Khodimi, 2016). These four conditions are straightly implemented in this research to ensure that they are used in the legal entity company as the sub-case.

\section{Results}

\section{The Bad Debt and its Implication on Micro and Macroeconomics}

To overcome an exigent condition or the lack of liquidity to meet short-term needs, getting into debt is the solution. The sources of debt are not only from a person but also from a financial institution. The banking institution is played a role as an intermediary unit to meet up between the deficit fund and the surplus of the fund units (Choudhury, 2008; Mankiw, 2009). On the other hand, the banking institution is obligated to share the profit with the depositor, and the customer is obligated to pay the bank their loan with its margin. Meanwhile, several creditors on bank institution experienced the financial ability decreasing to pay back their loans.

The bad debt has known as Non-Performing Financing (NPF). NPF is the term used in describing the financial customer who experienced the decreasing of financial abilities on repayment of the loans (Otoritas Jasa Keuangan, 2018). Referring to Central 
Bank of Indonesia's regulation (PBI) No. 13/2013, it is explained that NPF customer settlement took three paths of financial actions, namely restructuring, rescheduling, and reconditioning (Act law number 23 year 2011). In case of the implementation of these strategies does not run well, the banking institution will give the amnesty or write-off the loans after fronting several repressive actions (Hidayatullah, 2014).

The repressive action of the banking institution tends to result in disadvantages not only for the aggregate financial sector but also for customers. Looking from a financial perspective, the NPF inclines the negative spread of banking profitability (Alexandri \& Santoso, 2015; Kauko, 2012; Makri et al. 2014). In the financial framework view, facing a long run of negative portfolios might affect public trust. Public trust in the financial system is the key point to attract public attention to deposit their fund. Furthermore, lacking a third-party deposit in the bank implicates the degradation of the financing distribution through credits. Generally, the financial institution will be trapped in the negative spread of portfolios and might tend to get into failure.

NPF's customers will face various unwell implications in the financial litigation process, and lost his collateral (Ubaidillah, 2018) and felt the psychology distractions. On one side, the NPF's customers not only lost their asset through the litigation process but also trapped in the poorness. It is because financial ability decreasing to pay off the debt already shocked them in the harsh condition and it became worse if their collateral asset has confiscated. Further, Islam has mentioned several hadith of prophet Muhammad (PBUH) which warns his follower to be careful with the unpaid debt because it directly impacted personal matters in the world and hereafter. Thus, the unpayable debt has trapped both the person and the institutional debtor in various drawbacks such as individual psychology, social interaction (al-Qaradawi, 1973a), world and afterlife obstacles, financial institution profitability, and macro-economic (Arifin, 2002; Selma Messai \& Jouini, 2013).

The aggregate country macroeconomic has contented by all parties involved in the economic circle. One of the contributors to economic growth in a country is the industrial sector. The industrial sector has consisted of legal entities companies that produce goods and services for public needs. Furthermore, the company employs labors to assist the goods and services productions. The accumulative activities have measured as the company's contribution to economic growth through taxes obligation (Al-Utaibi, 1999). As a consequence, the higher sales made by the company, the higher tax paid to the state will be. In contrast, the degradation of the company's revenue affects the declining of the country's income.

As part of the responsibility from the Islamic religious teaching, the company is obliged to pay zakat. The zakat is not similar to the tax obligation. The tax is claimed as 
income of the state, while zakat has used for fulfilling public services through social activities. Therefore, the maintenance of production sustainability is necessary. It is because sales declining tends to reduce the company's revenue. As a result, the company less contributes to economic growth (Dahlan, 2018; Selma Messai \& Jouini, 2013) and social activities purposes. Further, the company will reduce the labors for the production efficiencies (Fisher, 1933). Subsequently, the implication of cut-off has been affecting the loss of personal revenue, in particular. The rising unemployment rate and the increasing of poor people have been dealing with general implications (AlFawzan, 2013; Nugroho et al. 2018).

Those disadvantages become worse if the capital sources of the company came from a financial institution. The macro implication would be more complex because the debtor's company is obligated to return its loans. The decreasing of the company ability repaying its loan to the bank will be affecting the internal financial position and external connecting-chain of the bank. Internally, facing Non-Performing Financing (NPF), the financial institution not only gains the negative spread on its portfolios (Alexandri \& Santoso, 2015) but also tends to enlarge the reserve (Mulianta Ginting, 2016) and reduces the credits to the customer (Melya Sari et al. 2012).

Expanding the reserve means that the banking institution is doing maintenance of the internal cash-flow. This action causes reducing the funding distribution for the deficit units that need financing. Because of it, the real sector might be affected by the degradation of financial credit (Effendi \& Thiarany, 2017; F Gracia \& Fretes Cibils, 2004). Stagnation of the production circle gives the drawbacks for aggregate economic. Furthermore, as the intermediary institution, it provides a source of fund, causing the bank unable to run its function well.

Consequently, the over-debt might become a cause of economic stagnation leading to the economic crisis (Ahmed, 2010). Therefore, to tackle those drawbacks, the legal entity company that shacked in burden debt must be assisted. In the zakat system, the shackled person who experienced the bad-debt is received support from zakat on behalf of gharim, while the failure company has not become part of gharim. On the other hand, the entity company has obligated to comply with the zakat payment. It is because the company has the same law with an individual under shaksun i'tibariyun.

\section{Zakat Obligation of the Legal Entity Company as a Legal Person}

Islamic scholars have expanded the scope of the zakat discourse. The expanding arises is on the object of wealth that must be issued and the subject who is obligated to pay zakat through the analogy method. For example, the zakat of stock or honey has not found the legal jurisprudence before. Nowadays, stock and honey become an object of zakat through analogy with the developed asset and the plantation zakat. Furthermore, the legal entities such as the business enterprise or the social non-profit organization 
have obligated to pay the zakat. Those are because of the entity company regarded as shaksun i'tibariyun that represents itself as a person.

As the shaksun i'tibariyun, the entity company has been regulated as the party who obligated to pay zakat. The initial reason for the zakat obligation on the legal enterprise has taken from the personal duty on zakat of trading. To this, Qaradawi mentioned that the zakat obligation of trade not only applied for the individual trader but also the legal entity company (al-Qaradawi, 1973b) because the developing asset that used for commercial purposes has been regarded as an object of zakat. The general obligation propositions of the zakat of trade can be found in Al-Quran QS. At-Taubah 9:103, which is mentioned about wealth purification by sadaqa or zakat (Hadi, 2016; Hafidhuddin, 2002; Septiawan \& Syamsul Bahri, 2019; Zaenal, 2019). Also, it can be found in the hadith of Muaz bin Jabal when he sent by Prophet Muhammad (PBUH) to Yaman to collect zakat from the society.

The logical arguments to obligate the legal entity company to pay zakat is analogous to the commercial trading of shaksun i'tibariyun to the individual business. The first argument is the zakat obligation mentioned in the Al-Quran and hadith that is principal and mandatory duty in which denying it becomes a kafir (who disobey an Islamic order). Following that, the order of zakat is included in financial worship. Islamic teachings said that every Muslim (mukallaf or ghayr mukallaf) have to pay zakat. The third, zakat in Islam is seen as the way to develop wealth. The last, the duty of zakat is not a voluntary action but a mandatory act for Muslims. The zakat has been obligated to the person who reaches the nisab. The zakat payment utilized to serve the rights of eight recipients (Zaenal, 2019). Further, because the commercial companies held the developing asset, they are obligated to pay annual zakat. Meanwhile, social foundations have not a duty to pay zakat because their purpose is to serve others through social and humanitarian activities.

There are several techniques to take zakat from a legal entity company. First, zakat is measured by the owner asset circulations. So, the zakat payment of the owner entitled to the company's zakat. Second, zakat is measured on the company's wealth as personal wealth on behalf of shaksun i'tibariyun. From this, the issued zakat of the company deployed on owner base on their own shares (Zaenal, 2020). As a consequence, if the zakat shared by the company does not reach the nisab (Zaenal, 2019), the issuing of zakat in this way requires additional wealth from the investor. The last way is to hand over the issuing zakat to the shareholders, which implied that the investor issues zakat personally and separately from the company. As a result, this technique provides only for the Muslim investors and the zakat was paid with accumulation with their-own assets. 
Among those techniques, the second payment model has a similarity with personal zakat because the legal entity regarded as one person. The zakat payment laid down on the owner caused the resumption of the company's claims. Thus, the analogy between the legal entity companies and personal that act as a person on behalf of shaksun i'tibariyun turns into aspects not only in the zakat obligation but also the derivative implication that includes the role of the zakat system in resolving the legal company debt trap that becomes the recipient of zakat on behalf of gharim.

\section{Company versus Personal Burden Debt}

In the state of urgency, Islam has been allowed its followers to make a loan to fulfil the daily need necessities. The debtor is not only allocated his debt consumptively but productively to meet basic needs and generate business activities. The debt utilizing consumptively or productively enable to trap the debtor in the burden debt (Yunus alMasri, 2005). The indebtedness person tends to disobey his obligation to pay off the loans. On the other hand, in the complying inability of this duty, Islamic teaching has provided zakat system to resolve it by entitling the indebtedness person under the gharim. The absence of the debtor's ability to comply with his debt puts him in dilemma conditions. It caused the loan payment creditor which was mandatory obligation to be fulfilled (Abdul Aziz et al. 2017; Cattelan, 2013).

Gharim as indebtedness person has divided into two categories, namely thoese who spend the debts for personal purposes (li maslahti nafsihi) and those who allocate the loans for others (li maslahati ghayrihi). The first category was the debtor shackled condition caused by the debt to meet personal-basic needs (i. e. foods, medicines, house building), and the second is the debt allocation for creating peace between the two groups in conflict (al-Qaradawi, 1973a). In the way, the debt allocation for personal purposes can be done consumptively or productively. Qaradawi argued that consumptive spending on the debt would be a gharim (al-Qaradawi, 1973a). Furthermore, the debt allocation for commercial purposes that has been entitled on behalf of gharim can be found on the zakat board in Sudan (Abdul Rahim, 2015).

The second category of gharim is indebtedness person shackled by debt which allocates it not only to resolve the conflict between the two parties but also to be used for social, religion, hospitals, humanitarian or educational purposes (al-Qaradawi, 1973a). Nowadays, those activities are held by individuals or legal entity organizations. Besides, most of them have embraced legal entity foundations that focus on serving others. Referring to Qaradawi and other scholars who said that the gharimin of this section receives zakat through their ability to pay off the debt because of their moral dignity in assisting others has huge implications than personal gharim (al-Qaradawi, 1973a).

The law of personal gharim in Islamic jurisprudence resolved that they can receive 
the zakat even though their debt is spent on individual needs or public purposes. Besides, the non-profit organizations or foundations is able to be designated as a gharim as long as the goals of these legal entities are providing social activities and public services (Hamdi 'Abdul Karim, 2016). Meanwhile, the commercial entity companies is not able to be entitled as gharim because they required a large amount zakat distribution which tends to reduce other asnaf's right (Abdul Rahim, 2015). Indonesian Zakat Board avoided distributing the zakat to the well-heeled person who shackled in the bad-debt for business purpose. From the economic perspective, the debt bondage of commercial companies affects several edges of human-life such as economic-growth runs steadily, rising unemployment, increasing the rate of poor people, and others.

To receive the zakat on behalf of gharim, some terms and conditions have to be fulfilled by the debtor. It is because not all loans will become on behalf of gharim. Those conditions continue to develop according to time and place. In a brief example, Qaradawi stipulated four conditions that must be complied by the debtor, namely the person under the burden-debt and under the urgency condition, and he did not have enough cash or asset to pay off his debt. Following that, the allocation of debt must be in the Islamic teaching framework (mubah). Moreover, the debt is already on the due date. The last condition is the debt that must correlate directly to other rights such as parents and needy person (al-Qaradawi, 1973a). On the other hand, those requirements is not able to globally be implemented in every single gharimin because their backgrounds are not similar. The purposes and the ploys of personal gharim on debt allocation are different from commercial legal entity companies or social organizations. Also, the debt impacts that followed both of them are not same.

Both company and personal debt are spent to meet a necessity. The company utilized the loan to expand its business scale. Company productivity enlargement implicated to increasing the labor requirement. The more employee employed in the company, the more revenue gained. The gross revenue of the company will be measure as tax. The tax directly contributed to national income and indirectly supported creating social welfare through public service. On the other hand, company bankruptcy will reduce most of its contribution to the state through taxes and provide employee income. Thus, it is different from the personal burden-debt, which affects personal and private matters.

\section{Discussion}

According to the first chapter of act law number 23 year 2011 entitled Zakat Management in Indonesia, point 5 and 10 mentioned that muzakki is the person or the legal entity obligated to pay zakat. The party who is obligated to pay zakat has expanded in recent decades. Until the International Congress in Kuwait in 1984s, the 
zakat obligation relay on the person who reached the nisab. Since the scholar's consensus of legal entity company has counted as a person on behalf of a legal person, most Islamic countries are obligated the company to pay zakat. Zakat payment duty upon the company is resulted from the analogy to a personal obligation.

The derivative implication of this analogy is the company that reached the nisab have to pay the zakat. The aggregate amount of zakat collection (included the zakat company) will be sufficient to fund recourses to alleviate poverty in Islamic countries (Shaikh, 2016). It means that the potential of zakat fitr, trade zakat, harvest, gold, silver, and the company gave a holistic impact on the ultimate goals of zakat, namely social welfare. On the one hand, the burden-debt experienced by the company has to support the zakat mechanism. It seems unfair if the shackled company is left behind to overcome his debt by himself, while in the profit condition he obligated to pay the zakat. The unwell circumstances caused by debt not only affected the person but also was even worse for the company.

In the financial regulation system, the bad-debt mitigation of the legal entity company has been well regulated. The regulation implied that the bank not only utilizes the fundraising from the third party but also feels disposed to resolve the NonPerforming Financing (NPF) customers. Banking institution faces several mechanisms to help the customer that experienced the degradation of financial ability, namely rescheduling, reconditioning, and restructuring. On the other hand, the final act that is taken by the banking institution to resolve the NPF is to write off the customer's loan or through the repressive action.

The financial bad-debt mitigation process runs in a complex mechanism for the customer to go through (Ubaidillah, 2018), even that the resolution tends to be won by the financial institution. The commercial company that cannot pay off its debt will be combating the financial institution in the commercial court. While in the process of the NPF mitigation, the companies might stop their production activities. As a result, revenue is declining, the labor is cut-off, the tax and zakat contribution to the country will be declining. Meanwhile, in the name of efficiency, the falling revenue forces the company to reduce labor. The cut-off of labor is not only affecting their income but also triggering the raising of the unemployment rate at the same time. It further contributes to the decreasing of the number of poverties.

The whole process tended to put the financial institution on a negative spread in its profit portfolios. Furthermore, the bad-debt accumulation in a bank institution influenced internal profit and external chain. The deficit unit that needs a fund might be obstructed to the financing because bank has expanded the liquidity reserve. The lack of liquidity in the real sector makes the stagnation of economic activities. The complex processes and their implications affected the country's economic growth in the 
long run. To tackle the drawbacks of the bad-debt can also be found in the Islamic economic system through zakat. In Islam, the zakat system not only becomes social security to provide human needs but also becomes social funding, as well as the mitigation of a person who unable to pay off this debt on behalf of gharim.

In Islamic teaching, unpayable debt mitigation has mentioned in the Al-Quran (QS. 2:280, 282) through the zakat mechanism. On the other side, Islamic jurisprudence has not mentioned the status of burden debt in the bankrupt company in the zakat system. The factual studies said that only the legal entity run the program for social purposes that is able to be supported by zakat (Hamdi 'Abdul Karim, 2016). Furthermore, some scholars put the amount that distribution to the bankruptcy companies tend to reduce the rights of other asnaf as the reasons for denying the zakat support to the bankruptcy enterprises (Abdul Rahim, 2015). According to the authors, referring to several implications on micro and macroeconomic, these arguments are no longer relevant. It further can be said that the legal entity company has already regarded as muzakki who is obligated to pay zakat.

At the first international congress on zakat in 1984 in Kuwait that was organized by the World Islamic Organization (OIC), the scholars agreed on analogous of the legal entities company as shaksun i'tibariyun to personal which resulted in the shaksun $i^{\prime}$ tibariyun that have the same rights and obligations as personal (Hafidhuddin, 2002). Based on the argument above, the legal entity companies regarded as a sector which obligated to issue the zakat (Zaenal, 2019). This policy also supported by Islamic scholars (al-Qaradawi, 1973a). Besides, regarding the legal entity companies as a personal, it enables to act like a person such as making a contract, agreement, trading transaction, and act as itself on the court.

The analogy of zakat payment between a legal entity company and a person is implementable in another case. For example, personal debt has lost his ability to repay the debt that might receive zakat on behalf of gharim. Meanwhile, the commercial company experiences financial failure and needs support to recover. Thus, the condition of both cases should be part of analogous. The Islamic scholars have used rational and logical argument in creating the zakat obligation for the legal company. Those arguments can be the reasons for the analogy between personal debt and legal entities debt. Further, the reason for entitling gharim as zakat recipient from personal debt should be found in the company loan.

Looking from the proposition in Al-Quran and the hadith as the legitimation of personal gharim that mentioned in QS. At-Taubah 9:60 "fi...al-gharimin...". The word " $f i$ " means the debt bondage condition which experienced by the personal debtor. The word "al-gharimin" refers to the actor who utilizes the loan. Based on the authors' 
investigation, there is no single scholars mentioned the word "al-gharimin" to only refers to personal gharim but it refers to a person or not. It is because al-Qaradawi (1973a) has stated that the gharimin in the QS. 9:60 mean the loan for personal matters and for public purposes, which both of them enable to be gharim. Furthermore, he said the positive activity that was not only for personal but also for a group of people on behalf of their organization. It means that the gharimin includes a person and legal entity, while the legal entity regulated as shaksun i'tibariyun has the same legal implication as a person.

Furthermore, referring to the terms and condition that must be fulfilled by the personal gharim to receive zakat, they mostly can be found in the debt-shackled company. Likewise, the debt must be in the Islamic framework, the urgency while getting into debt, and the due date of the debt. First, for sure that the legal company propose in this paper is the commercial company that must be in line with the Islamic teaching framework. For instance, the source of the fund must be gained from Islamic financial institution and the production, process and distribution of goods and services must be in halal compliances. Second, the debt allocation of company debt has spent on the production of goods and services. Meanwhile, with debt the legal company created opportunities for people to get a job. Furthermore, the commercial company assisted people in receiving wages, which utilized to meet the necessity of families.

To this, the legal entity company utilized the loan for broader purposes than personal debt utilization. While the personal gharim uses debt for individual needs, the commercial company uses it for public purposes. Then, getting into the bad-debt affected the internal and influenced macro-economic such as economic stagnation that contributed to triggering the crisis. Further, the implications tend to raise the unemployment and poverty rate that affected social welfare (Nugroho et al. 2018). Qaradawi stated that the background for distributing zakat to the social purposes gharim is because they have a noble attitude on helping others. He said that spending debt on public purposes is more necessary to receive the zakat than allocating debt for personal needs. Thus, the legal entity company as gharim also becomes a priority than personal gharim because it has larger implications.

The third is the due date of the debt. In the bad-debt mitigation mechanism, the failure of the commercial company has held by the commercial court. It means that the legal decision of the court has a binding legal force to entitle the bankruptcy. Therefore, the bankruptcy decision has transformed into a disaster for the company. It also becomes a crumble for the workers who depend their life on the company. Thus, if the personal gharim that shackled by the debt will affect his own life, for the legal entity, the company shackled in the bad-loans turn the complex implications. Therefore, the entity company was already entitled as muzakki to pay the zakat. Due to the shackled condition experienced by the entity company, the zakat must come to support them 
through gharim. The last of that, this paper contradicted Hamdi's opinion that stated only the legal entities engage in the social sector can be designated as gharim (Hamdi 'Abdul Karim, 2016).

In line with this, the findings of this paper implicate theoretical and practical implications. In the theory aspect, the debt-shackled company, which designated as a recipient under the group of gharim has contributed to the expansion of the gharim category in Islamic philanthropy institution. Furthermore, it will re-construct the zakat distribution, especially gharim. Practically, the findings of this study tends to reduce the personal gharim portion since the debt-shackled company becomes a gharim. Meanwhile, this paper did not conduct the simulation of term and condition that have to be fulfilled by the legal entity company to become gharim. Thus, future research can take a role to fill the limitation of this paper.

\section{Conclusion}

This paper uncovers the debt status of the legal entity company under the gharim framework. The person in the burden debt which disable to repay his debt becomes the reason to entitle him as the recipient of zakat on behalf of gharim, while the shackled company is not. On the other hand, since the first international congress of zakat in Kuwait in 1984s, the legal entity company has obligated to issue the zakat. It caused by the analogy between a legal person (shaksun i'tibariyun) and a person representing the enterprise counted as a person in the zakat of trade. The logical reasons of the analogy between a person and legal company and its disadvantages arise from a shackled company through macroeconomic that is fit as a mitigation tool of the shackled company through zakat system on behalf of gharim.

By employing a library research through the ijtihadi method, this paper found that the debt status of a legal entity company that trapped in the burden debt for commercial purposes was eligible to receive zakat on behalf of gharim. It further found that the shackled companies in the burden debt emerge disadvantages of micro and macro implications that influence the economic circle in the country. The impact of the company's bad-debt was larger than the personal burden debt. The result of this paper fills the gap in the discourses of the gharim category. The existing work has divided the gharim into an individual and social foundation (Hamdi Abdul Karim, 2016), while this paper proposed that a commercial company should become zakat recipient under the gharim group. Although this paper discloses several interesting findings, the gharim analysis attempted in this paper is limited to examining the debt status and economic implications of the debt shackled company. Therefore, future research can enhance further analysis on the practical terms and conditions for legal entity company to receive zakat on behalf of gharim. 


\section{Authors' Declaration}

The authors made substantial contributions to the conception and design of the study. The authors took responsibility for data analysis, interpretation and discussion of results. The authors read and approved the final manuscript.

\section{ORCID}

Eja Armaz Hardi (1D https://orcid.org/0000-0002-4266-2358

Sirajul Arifin (1) https://orcid.org/0000-0001-9900-2855

Burhan Djamaluddin (1D https://orcid.org/0000-0002-2411-6265

\section{References}

Abdul Aziz, I., Azrin Adnan, A., \& Asmat Ismail, N. (2017). Fenomena Keberhutangan di Zaman Rasulullah. Ulwan Journal, 1(1), 143-177.

Abdul Rahim, A. (2015). Al-Tajarub al-Mu'asirah litatbiqat Masharif al-Gharimin fi alZakah. Majma, 13, 303-340.

Abdullah \& Haqqi, A. R. A. (2017). Zakat for Asnaf Al-Gharimun in Brunei Darussalam: Concepts and Practices. Al-Iqtishad: Jurnal Ilmu Ekonomi Syariah, 9(2), 243-258. http://dx.doi.org/10.15408/aiq.v9i2.5092

Ahmed, A. (2010). Global Financial Crisis: An Islamic Finance Perspective. International Journal of Islamic and Middle Eastern Finance and Management, 3(4), 306-320. DOI:10.1108/17538391011093252

al-Qaradawi, Y. (1973a). Figh al-Zakah (Vol. 2). Beirut: Muassasah al-Risalah. al-Qaradawi, Y. (1973b). Figh al-Zakah (Vol. 1). Beirut: Muassasah al-Risalah. Alexandri, M. B., \& Santoso, T. I. (2015). Non Performing Loan: Impact of Internal and External Factor (Evidence in Indonesia). International Journal of Humanities and Social Invention, 4(1), 87-91.

AlFawzan, F. A. (2013). The Existence of Relationship Between Debt and Recession. Arab Journal of Administrative Sciences, 20(2), 323-339.

Al-Utaibi, A. T. (1999). Towards a Unifield System of Zakat Accounting: The Case of The GCC Countries (Ph. D Thesis). Cardiff Business School, Cardiff University, Wales, UK.

Amin al-Shinkity, M. (2001). Muzhakirah fi Usul Al-Fiqh. Medinah Munawarah: Maktabah Al-Ulum wa Al-Hikam.

Arifin, Z. (2002). Dasar-Dasar Manajemen Bank Syariah. Jakarta: Alvabet.

BAZNAS. (2019). Keputusan Ketua Badan Amil Zakat Nasional Nomor 64 Tahun 2019 tentang Pedoman Pelaksanaan Pendistribusian dan Pendayagunaan Zakat di Lingkungan Badan Amil Zakat Nasional. , Pub. L. No. 64, 1 (2019).

Bensaid, B., Grine, F., Roslan Mohd Nor, M., \& Yakub Zulkifli Mohd Yusoff, M. (2013). Enduring Financial Debt: An Islamic Perspective. Middle-East Journal of Scientific Research, 13(2), 162-170. DOI: 10.5829/idosi.mejsr.2013.13.2.1790

Cattelan, V. (2013). Property (Māl) and Credit Relations in Islamic Law: An Explanation of Dayn and the Function of Legal Personality (Dhimma). Arab Law Quarterly, 27(2), 189-202. https://doi.org/10.1163/15730255-12341255 
Choudhury, M. A. (2008). The Universal Paradigm and The Islamic World-System: Economy, Society, Ethics, and Science. Singapore: World Scientific Publishing Co. Pte. Ltd.

Dahlan, D. (2018). Bank Zakat: Pengelolaan Zakat dengan Konsep Bank Sosial Berdasarkan Prinsip Syariah. Jurnal Ekonomi Dan Bisnis Islam, 4(2), 166-153. http://dx.doi.org/10.20473/jebis.v4i2.10720

Effendi, J., \& Thiarany, U. (2017). Factors Influencing Non-Performing Financing (NPF) at Shariah Banking. Walisongo: Jurnal Penelitian Sosial Keagamaan, 25(1), 109-138. https://doi.org/10.21580/ws.25.1.1540

F Gracia, V., \& Fretes Cibils, V. (2004). Remedy for Banking Crises: What Chicago and Islam Have in Common. Islamic Economic Studies, 11(2), 1-22.

Fauzia, A. (2017). Islamic philanthropy in Indonesia: Modernization, Islamization, and social justice. Austrian Journal of South-East Asian Studies, 10(2), 223-236. https://doi.org/10.14764/10.ASEAS-2017.2-6

Fisher, I. (1933). The Dept Deplation Theory of Great Depressions. Econometrica, 1(4), 337-357. https://doi.org/10.2307/1907327

Hadi, C. A. (2016). Corporate Social Responsibility dan Zakat Perusahaan dalam Perspektif Hukum Ekonomi Islam. Ahkam, 16(2), 229-240. http://dx.doi.org/10.15408/ajis.v16i2.4453

Hafidhuddin, D. (2002). Zakat dalam Perekonomian Modern. Jakarta: Gema Insani. Hakim, R. (2018). Kontekstulalisasi Fikih Golongan Penerima Zakat (asnaf tsamaniyah) Zakat dan Relevansinya dengan Penanggulanan Kemiskinan di Indonesia. 2nd Annual Conference for Muslim Scholar, 2nd, 393-406. Surabaya: UIN Sunan Ampel Surabaya.

Hamdi Abdul Karim, K. (2016). al-Ahkam al-Fiqihiyah al-Muta'aliqah bisahmi algharimim: Nazrah shar'iyah maqasidiyah mu'asirah. Majma': Majalah Jami'ah alMadinah al-'alamiyah, 16, 8-68.

Hamzah, N. B., Masroom, M. N. B., Ruskam, A. B., \& Saim, A. I. B. (2021). Penggunaan Wang Bantuan Zakat Dalam Kalangan Asnaf Fisabilillah Dan Asnaf Gharim Di Universiti Teknologi Malaysia. AZKA International Journal of Zakat $\mathcal{E}$ Social Finance, 1(2), 187-209. https://doi.org/10.51377/azjaf.vol1no2.37

Hardi, E. A. (2020). Filantropi Islam: Zakat Saham di Pasar Modal Syariah Indonesia. Jurnal Bimas Islam, 13(1), 51-72. https://doi.org/10.37302/jbi.v13i1.106

Hidayatullah, M. F. (2014). Penyelesaian Pembiayaan Bermasalah di Bank Syariah. Interest, 12(1), 67-80.

Ibrahim, M. F. (2020). Perbandingan Agihan Zakat sebagai Alat Kewenangan Sosial Islam bagi Membantu Golongan al-Gharimin oleh LZS dan Baitulmal MAIWP. International Journal of Islamic Economics and Finance Research, 3(2), 1-11.

Ibrahim, M. F., \& Sahrim, M. (2019). Peranan Agihan Zakat sebagai Alat Kewenangan Sosial Islam bagi Melaksakan Hutang Golongan al-Gharimin di Malaysia. Labuan E-Journal of Muamalat and Society (LJMS), 13, 45-53.

Jiyad, A. M. (2001). An Economy in Debt Trap: Iraqi Debt 1980-2020. Arab Studies Quarterly, 23(4), 15. 
Kauko, K. (2012). External Deficits and Non-Performing Loans in the REcent Financial Crisis. Economics Letters, 115, 196-199. https://doi.org/10.1016/j.econlet.2011.12.018

Latief, H. (2016). Philanthropy and "Muslim citizenship" in post-Suharto Indonesia. Southeast Asian Studies, 5(2), 269-286. https://doi.org/10.20495/seas.5.2_269

Makri, V., Tsagkanos, A., \& Bellas, A. (2014). Determinants of Non-Performing Loans: The Case of Eurozone. Panoeconomicus, 2, 193-206. https://doi.org/10.2298/PAN1402193M

Mankiw, G. (2009). Princples of Economics (Sixth, Version Sixth). USA: South-Western Cengage Learning

Melya Sari, T., Syam, D., \& Ulum, I. (2012). Pengaruh Non-Performing Loan sebagai Dampak Krisis Keuangan Global Terhadap Profitabilitas Perusahaan Perbankan. Jurnal Akuntansi Dan Investasi, 13(2), 83-98.

Mukhtar al-Khodimi, N. (2016). Ta'lim Ilmu Al-Usul. Riyadh: Maktabah Al-abikan. Mulianta Ginting, A. (2016). Pengaruh Makroekonomi Terhadap Non-Performing Loan (NPL) Perbankan. Jurnal Ekonomi Dan Kebijakan Publik, 7(2), 159-170. http://dx.doi.org/10.22212/jekp.v7i2.669

Nugroho, L., Hidayah, N., \& Badawi, A. (2018). The Islamic Banking, Asset Quality: "Does Financing Segmentation Matters" (Indonesia Evidence). Mediterranean Journal of Social Sciences, 9(5), 221-235. https://doi.org/10.2478/mjss-2018-0154

Otoritas Jasa Keuangan. (2018). Peraturan Otoritas Jasa Keuangan Republik Indonesia Nomor. 35/POJK.05/2018 tentang Penyelenggaraan Usaha Perusahaan Pembiayaan. , Pub. L. No. 35, 05 POJK (2018).

Selma Messai, A., \& Jouini, F. (2013). Micro and Macro Determinants of NonPerforming Loans. International Journal of Economics and Financial Issues, 3(4), 852860.

Septiawan, H., \& Syamsul Bahri, E. (2019). Tinjauan Zakat Perusahaan Perspektif Syariah dan Regulasi. Kordinat, 18(2), 339-375.

https://doi.org/10.15408/kordinat.v18i2.11495

Shaikh, S. A. (2016). Zakat Collectible in OIC Countries for Poverty Alleviation: A Primer on Empirical Estimation. International Journal of Zakat, 1(1), 17-35. https://doi.org/10.37706/ijaz.v1i1.4

Spradlley, J. A. (1979). Metode Ethnografi. Yogyakarta: Tiara Wacana.

Ubaidillah. (2018). Pembiayaan Bermasalah pada Bank Syariah: Strategi Penanganan dan Penyelesaiaannya. El-Jizya: Islamic Economics Journal, 6(2), 287-310. https://doi.org/10.24090/ej.v6i2.2042

Undang-Undang Republik Indonesia. (2011). UU RI Nomor 23 tahun 2011 tentang Pengelolaan Zakat. , Pub. L. No. 23, 23 Nomor 23 tahun 2011.

Yunus al-Masri, R. (2005). Expenditure on Al-Gharimin (Person Under the Burden Debt) and Its Impact on Social Security. Al-Iqtisad al-Islamy, 18(1), 3-27.

Yusof, S. M., \& Tahir, R. M. (2015). Analisis tafsiran asnaf al-gharimin di Malaysia. International Journal of Management Studies, 22, 81-100.

Zaenal, M. H. (2019). Fikih Zakat Perusahaan (Vol. 3). Jakarta: Books-Puskas Baznas. Zaenal, M. H. (2020). Indeks Zakat Saham Perusahaan (IZS) (Vol. 4). Jakarta: Books- 
Eja Armaz Hardi, Sirajul Arifin, Burhan Djamaluddin: The Debt Status of Commercial Company under Gharimin Perspective

Puskas Baznas. 